\title{
СТРУКТУРНОЕ ПОЛОЖЕНИЕ И ПЕТРОГЕОХИМИЧЕСКИЕ ОСОБЕННОСТИ ДАЕК АНДЕЗИБАЗАЛЬТОВ СЕВЕРНОГО ОБРАМЛЕНИЯ ПЕЧЕНГСКОЙ СТРУКТУРЫ
}

\author{
Терехов Е.Н. ${ }^{*}$, Морозов Ю.А. ${ }^{2}$, Смолькин В.Ф. ${ }^{3}$, Баянова Т.Б. ${ }^{4}$, Щербакова Т.Ф. \\ ${ }^{1}$ Геологический институт PAH, Москва, tereh@ilran.ru \\ ${ }^{2}$ Институт физики Земли им. О.Ю. Шмидта РАН, Москва \\ ${ }^{3}$ Государственный геологический музей им. В.И. Вернадского РАН, Москва \\ ${ }^{4}$ Геологический институт КНЦ РАН, Апатить
}

В последние годы весьма популярна идея о так называемом «эндогенном покое» или « magmatic shutdown» для периода 2.45-2.2 млрд. лет, когда по каким-то причинам заметно снизилась магматическая активность. Для этого же периода известны самые древние признаки оледенения, а также предполагается смена бескислородной атмосферы на кислородную [2]. Действительно, как показывает анализ возрастов детритовых цирконов из аллювия крупнейших рек, а также анализ возрастов гранитов из конвергентных окраин плит (естественно в их авторской трактовке), для периода 2.45-2.2 млрд. лет наблюдается естественный провал на графиках частоты встречаемости возрастов [9]. Для исследователей Балтийского щита подобная идея выглядит довольно странно, так как для этого периода известно довольно много определений возраста, хотя часть их безусловна весьма спорная и требует дополнительных исследований. В тоже время сариолийский и ятулийский возраст (2.4-2.3 и 2.3-2.1 млрд. лет соответственно) для многих образований восточной части Фенноскандинавского щита достаточно хорошо документирован геологическими наблюдениями: картированием вулканогенно-осадочных толщ или структурными исследованиями взаимоотношений магматических тел $[1,3]$.

На фоне изучения причин «эндогенного покоя» становится вновь актуальной проблема появления андезибазальтов сариолийского возраста (2.4-2.3 млрд. лет) в основании Печенгской структуры. В период становления идей тектоники плит для раннего докембрия эти породы, преимущественно по геохимическим характеристикам, так или иначе сравнивались с островодужными образованиями [10], тогда как структурно-геологические построения противоречат этому и интерес к этим образованиям постепенно угас. При этом появилось достаточно много данных о породах базальтового состава в пределах Карелии, имеющих возраст 2.4-2.3 млрд. лет. Подобная магматическая зональность вероятнее всего отражает неоднородности в земной коры, причины образования которой изложены ниже.

Нами проведены структурные и геохимические исследования двух участков распространения даек андезибазальтового состава: Лиинахамари и губы Амбарная, которые являются комагматами вулканитов маярвинской свиты Печенгской структуры, что позволяет с принципиально новых позиций обсуждать геодинамическое положение этих магматических проявлений. В пределах дайкового роя губы Амбарная опробованы все типы даек, различающие по мощности и по падению. Все дайки оказались близкими по химическому и минеральному составу. Кварцевые долериты формируют гомогенную группу пород с содержанием $\mathrm{MgO}$ от 4 до 7 \%, с низкими концентрациями $\mathrm{Cr}$ (10-50 г/т) и умеренными - Y, Zr, REE. Установлены слабо фракционированные спектры тяжелых Р3Э $(\mathrm{Gd} / \mathrm{Yb})_{\mathrm{n}}$ (не более 1.6) на фоне заметного обогащения $(\mathrm{La} / \mathrm{Sm})_{\mathrm{n}}=2.6-2.9$, незначительной отрицательной Еu аномалией 0.87-0.9 и общего фракционирования $(\mathrm{La} / \mathrm{Yb})_{\mathrm{n}}=5.1-5.8$. Породы обогащены крупноионными литофильными элементами: Rb, Ba, K, обеднены $\mathrm{Nb}$, Ti, имеют низкие $\mathrm{Sr} / \mathrm{Y}=11-13$. Изученные дайки недифференцированые, поэтому их состав может соответствовать исходным магмам, что позволяет реконструировать геодинамические условия их генерации. Отсутствие зон закалок в дайках свидетельствует об относительно повышенной температуре вмещающих пород и отсутствии летучих.

Для изотопных исследований была выбрана наиболее крупная дайка андезибазальтового состава, расположенная 69³9'58.16"С и 31039'57.63"В. Изотопный U-Pb-возраст циркона из этой дайки определен в $2304 \pm 1$ млн. лет. Эти данные позволяют более уверенно коррелировать дайковый узел губы Амбарная с дайками пос. Лиинахамари и вулканитами маярвинской свиты Печенгской 


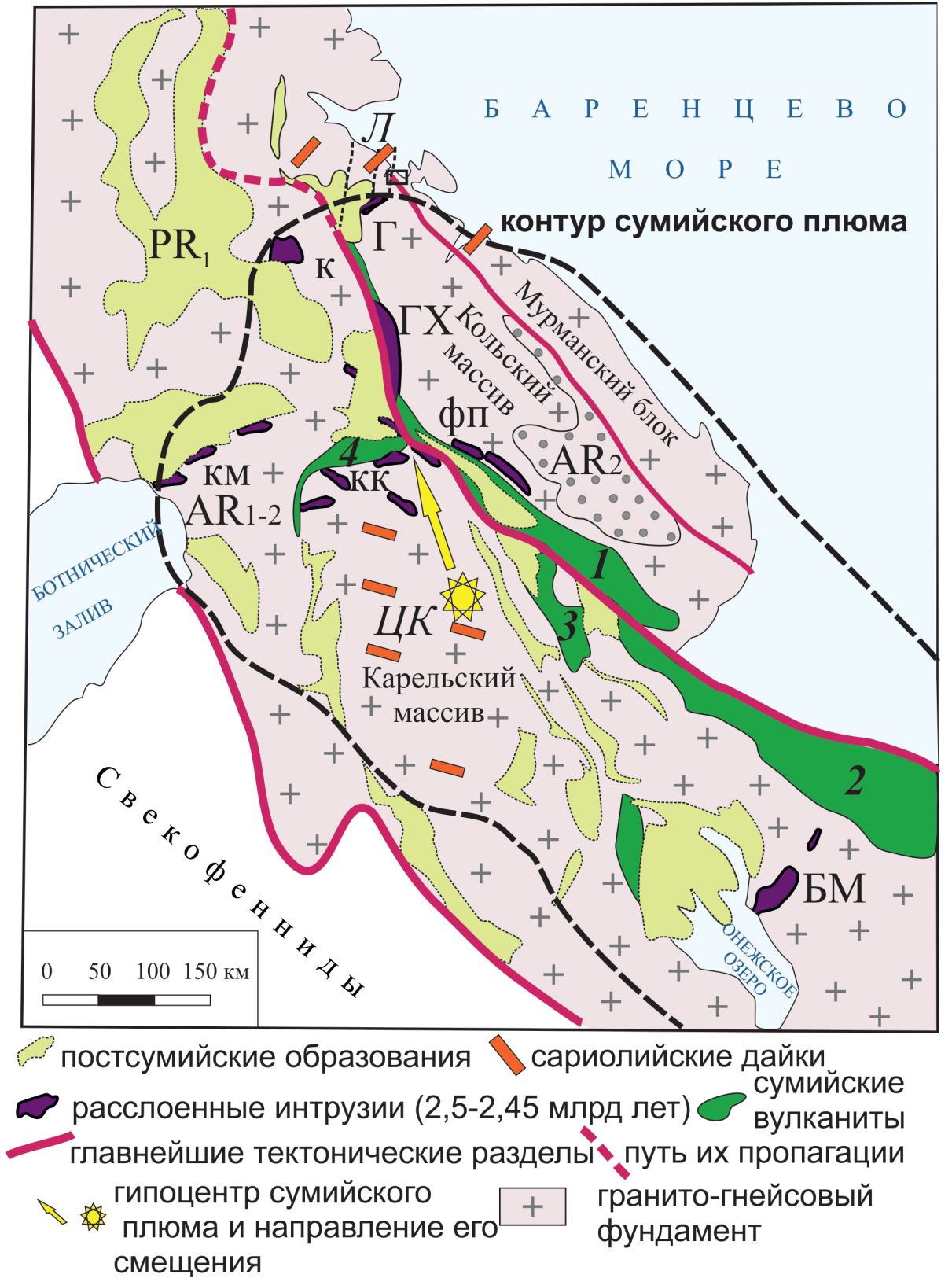

Рис. 1. Геологическая схема Восточной части Балтийского щита на период 2.3 млрд. лет назад

(Для ориентировки показаны некоторые элементы современной гидрографии).

Дайковые рои (2.3 млрд. лет): Л - Лиинахамари, ЦК - Центрально-Карельский. Троги сумийского возраста (2.5-2.4 млрд. лет), заполненные базальтами, коматиитами и андезитами: 1 - Имандра-Варзугский, 2 - Ветреного Пояса, 3 - Лехтинско-Шомбозерский, 4 - Северо-Карельский. Расслоенные интрузии (2.55-2.45 млрд. лет): БМ - Бураковско-Монастырский, ФП - Федоро-Панский, КК- Кивакка-Кундозеро, КМ - группа Кеми, ГХ - Главный Хребет и Мончеплутон, Г- Гора Генеральская, К - Койтелайнен.

структуры. Из той же дайки, из её ксенолитов мощностью до 5 м, были изучены пробы гранитов и плагиогранитов с целью определения их изотопного возраста и оценки роли термального воздействия расплава дайки на вмещающие породы. Граниты и плагиограниты содержат по три вида цирконов, близких по морфологии. Изотопный U-Pb возраст плагиогранитов $-2722 \pm 4$ млн. лет, $\mathrm{CKBO}=0.67$. Нижнее пересечение дало возраст $366 \pm 15$ млн. лет, что перекрывается с этапом формирования интрузий Кольской щелочной провинции. Возраст гранитов оказался существенно моложе $-2418 \pm 8$ млн. лет, СКВО =0.29, что вероятно отражает обстановку растяжения, предшествующую формированию Печенгской структуры.

В восточной части Фенноскандинавского щита для палеопротерозойского этапа выделяется два крупных тектономагматических события, которые ассоциируются с плюмовой активностью и 
формированием рифтогенной системы карелид [6], состоящей из нескольских сдвиговых зон, в которых формировались троги пулапартного типа, выполненные бимодальной серией с незначительным количеством осадков. Помимо вулканитов, сумийское плюмовое событие (2.5-2.4 млрд. лет) проявилось в формировании большого числа расслоенных интрузий, даек, массивов друзитов и габбро-анортозитов. Проекция этого плюма на современную поверхность образует овал $550 \times 950$ км по длинной оси вытянутой в С3 направлении в современных координатах [5]. Максимальная мощность сумийских вулканитов отмечается в юго-западной Карелии и в центре Кольского п-ова (структуры: Ветреного Пояса и Имандра-Варзугская) с постепенным их уменьшением в С3 направлении (рис. 1). Граница этого плюма, могла находиться в районе Печенгской структуры, где расположен массив горы Генеральской, а вулканиты этого возраста отсутствуют. Следующий импульс магматизма, который также связан с мантийным плюмом, приходится на временной интервал 2.3-2.0 (1.9 млрд. лет) $[5,6]$. При этом область максимального развития вулканитов смещается на северо-запад. Это структуры: Печенгская, Куолоярви, Киттеля-Салла, Карасъек и Каутокейна (рис. 1) Особенностью вулканитов этого периода является наличие MORB-базальтов и «обогащенных» ферропикритов с высокими содержаниями LREE, которые часто переслаиваются в едином разрезе. Разница в составе пород, характерных для этих плюмовых событий, отражает различные условия развития структур подчиненных плюму, или различному составу верхней мантии и коры, в пределах которых развивается зона плавления плюма. Судя по распространению магматических образований того и другого возраста, можно предполагать смещение центра магматической активности в северо-западном направлении (в современных координатах). В пределах Печенгской структуры сумийских образований нет, а её разрез начинается с сариолийских конгломератов и вулканогенной толщи андезибазальтового состава с возрастом 2.3 млрд. лет. За период 2.4-2.2 млрд. лет произошло смещение области вулканической активности и пропагация оси мантийного поднятия и рифтовых структур, к которым приурочены вулканиты [7]

Учитывая одновозрастность даек кварцевых долеритов и их сходство с вулканитами маярвинской свиты Печенгской структуры, можно предполагать, что исследуемые дайки являлись подводящими каналами для вулканов, впоследствии уничтоженных в результате эрозии и тектонической денудации. Таким образом на рубеже 2.3 млрд. лет шло формирование андезибазальтов маярвинской свиты Печенги и исследуемых даек. В это же время в Карелии, в центральной части области сумийского магматизма, формировались дайковые рои исключительно базальтового состава [5]. Поэтому можно предполагать, что вулканиты Печенгской структуры, так же, как и дайки роя ЛиинахамариАмбарная губа, образовывались в краевой части «отмирающего» сумийского плюма и на участке пропагации палеопротерозойской рифтогенной системы [7]. Вполне возможно, что постепенный (?) переход к обстановке регионального сжатия по сравнению с центральной части плюма, отразился и на геохимической специализации андезибазальтовых магм, обогащенных литофильными элементами. Это сближает их по составу с андезитами - характерными образованиями зон современной субдукции.

Таким образом, на примере восточной части Фенноскандинавского щита можно говорить о некой условности выделения «эпохи эндогенного покоя» так как в этот период происходила смена тектонического режима с появлением продуктов магматической активности бедных цирконами, что и проявилось на графиках распределения $\mathrm{U} / \mathrm{Pb}$ возрастов детритовых цирконов.

Исследования выполнены в рамках темы госзаданий ГИН РАН № 0135-2016-0012, ИФЗ РАН № 0144-2014-0089-11 и при финансовой поддержке РФФИ грант № 17-05-00592 и программы Президума РАН 19 проект№0135-2018-0040.

\section{Литература}

1. Арзамасцев А.А. Федотов Ж.А. Арзамасцева Л.В. Дайковый магматизм Северо-Восточной части Балтийского щита. СПб.: Наука. 2009. 383 с.

2. Игнатьев А.В. Ханчук А.И., Высоцкий С.В., Веливецкая Т.А., Левицкий В.И, Терехов Е.Н. Первые данные масс-независимого фракционирования изотопов серы в сульфидах из пород восточной части Фенноскандинавского щита // ДАН. 2016. Т. 469. № 6. С. 714-718. 
3. Морозов Ю.А., Галыбин А.Н., Мухамедиев Ш.А., Смульская А.И. // Тектонический и геомеханический контроль морфологии и пространственного размещения систем даек и силлоподобных тел в деформируемой среде (на примере С3 части Кольского полуострова) Геотектоника. 2017. № 3. С. 28-60.

4. Смолькин В.Ф., Кременецкий А.А., Ветрин В.Р. Геолого-геохимическая модель формирования палеопротерозойских (2.5-2.4 млрд. лет) рудно-магматических систем Балтийского щита // Отечественная геология. 2009. № 3. С. 54-62.

5. Степанова А.В., Сальникова Е.Б., Самсонов А.В., и др. Проявление внутриплитного магматизма на Карельском кратоне 2,3 млрд лет назад: к проблеме эпохи «эндогенного покоя» в палеопротерозое // Докл. АН. 2014. Т. 457. № 4. С. 460-465.

6. Терехов Е.Н. Лапландско-Беломорский подвижный пояс как пример корневой зоны палеопротерозойской рифтовой системы Балтийского щита // Литосфера. 2007. № 6. С. 15-39.

7. Терехов Е.Н., Морозов Ю.А., Смолькин В.Ф., Баянова Т.Б., Щербакова Т.Ф. О проявлении дайкового магматизма андезит-базальтового состава в палеопротерозойской рифтогенной системе Кольского кратона Докл. АН. 2018. Т. 479. № 3. С. 302-308.

8. Conde K.C., O,Neill C., Aster R.C. Evidence and implications for a widespread magmatic shutdown for 250 My on Earth // Earth and Planetary Science Letters.2009. V. 282. P. 873-878.

9. Kuznetsov N.B., Belousova E.A., Alekseev A.S. and Romanyuk T.V. New data on detrial zircons from the sandstones of the lover Cambrian Brusov Formation (White Sea region, East-European Craton): unraveling the timing of the onset of the Arctida-Baltica collision // International Geology Review. 2014. P. 1-19.

10. Marker M. Early Proterozoic (c 2000 - 1900 Ma) crustal structure of the northeastern Baltic Shield: tectonic division and tectogenesis // Nor. Geol. Unders. Bull. 1985. № 403. P. 55-74. 